\title{
A new species of Glinus L. (Molluginaceae) from the Northern Territory, Australia
}

\author{
P. S. Short
}

\begin{abstract}
Short, P.S. (Northern Territory Herbarium, Parks \& Wildlife Commission of the Northern Territory, P.O. Box 496, Palmerston, NT 0831, Australia) 2002. A new species of Glinus L. (Molluginaceae) from the Northern Territory, Australia. Telopea 9(4): 761-763. Glinus sessiliflorus, a species restricted to the Top End of the Northern Territory, is described and illustrated. It differs from other Australian species in having solitary, sessile flowers and two stamens per flower. A key to the four species of Glinus in Australia is provided.
\end{abstract}

\section{Introduction}

During compilation of an account of the family Molluginaceae in the Northern Territory it became apparent that an undescribed species of Glinus occurs in the Top End. It is described herein.

Species of Glinus L. are generally characterised by being herbs with flowers in axillary whorls or fascicles and by having seeds with a caruncle which terminates in a long, filiform appendage. These features are used to differentiate them from species placed in Mollugo, members of that genus having flowers borne in cymes or panicles and producing seeds which either lack a caruncle or have a very small caruncle which lacks an appendage. Perhaps not surprisingly Glinus is sometimes (Fosberg 1995) treated as a section of Mollugo and there may be merit in this action. However, as the aim of this paper is to simply make a formal name available for the species here described I have opted to follow the practice in current Australian State floras and accept Glinus as a distinct genus.

\section{Taxonomy}

Glinus sessiliflorus P.S. Short, sp. nov.

G. oppositifolius similis sed ei in floribus solitariis, sessilibus et in floribus staminibus binis differt.

Holotype: Northern Territory: Yinberrie Hills, Edith River area, $14^{\circ} 04^{\prime} 58^{\prime \prime} \mathrm{S}, 132^{\circ}$ $04^{\prime} 58^{\prime \prime} \mathrm{E}$, common on alluvial clay depressions, 30 June 2000, C.R. Michell 2504 (DNA 142356).

Isotype: CANB.

Annual herbs with prostrate stems to c. $12 \mathrm{~cm}$ long, with simple, white, straight to somewhat curled, spreading hairs scattered to dense on young growth. Leaves shortly to manifestly petiolate; petiole c. $0.5-11 \mathrm{~mm}$ long; lamina mostly circular to elliptic or very widely obovate to obovate, occasionally oblanceolate, $1-15 \mathrm{~mm}$ long, $0.8-5 \mathrm{~mm}$ wide, margins entire, with simple hairs as on branches. Flowers single, axillary, sessile. Perianth segments 5, free, elliptic to narrowly elliptic or obovate, 1.9-3 mm long, 
0.6-1.1 mm wide; 2 or 3 segments mainly herbaceous but others with pronounced, whitish, scarious margins, the herbaceous parts of all segments sparsely to manifestly hairy. Stamens 2. Ovary glabrous, trilocular, placentation axile. Styles 3, sessile or almost so. Capsule 1.6-3 mm long, 3-valved, enclosed within the perianth. Seeds subreniform, $0.33-0.4 \mathrm{~mm}$ long, shiny reddish brown, smooth or tuberculate; with a white caruncle with a slender appendage around the periphery of the seed. Fruiting: June-Dec. (Fig. 1).
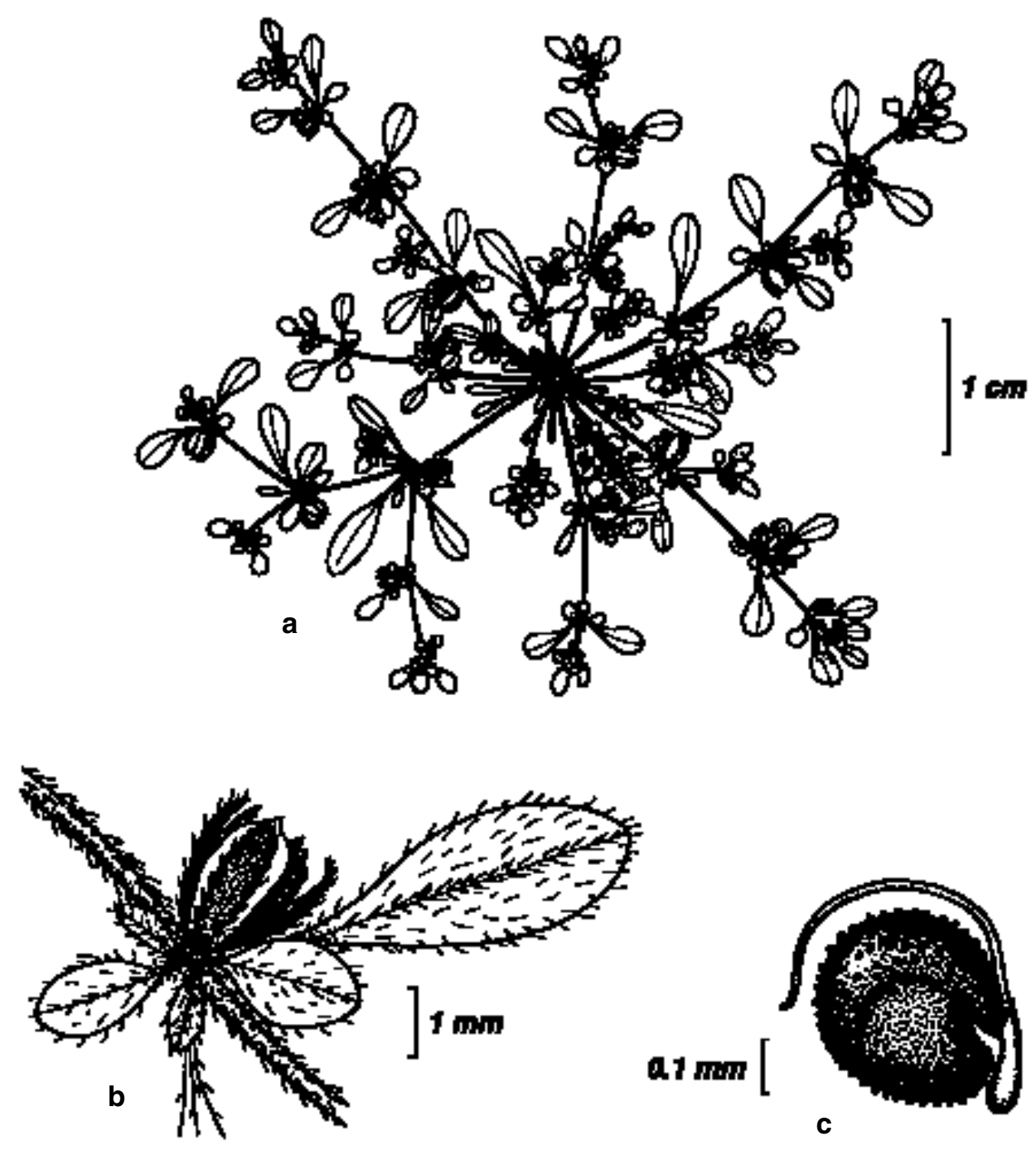

Fig. 1. Glinus sessiliflorus. a, habit; $\mathbf{b}$, flowering node, the flower with a nearly mature capsule; c, seed. All illustrations from the type collection. 
Etymology: the specific epithet reflects the sessile flowers, a key distinguishing feature of this species.

Distribution: confined to the Top End of the Northern Territory.

Habitat: at Ja Ja recorded from open grassland on the fringe of the floodplain and in the Edith River region in alluvial clay in a drainage depression.

Conservation status: possibly adequately conserved, with the Ja Ja and Nourlangie Rock populations in Kakadu National Park.

Notes: The few specimens of G. sessiliflorus in DNA have been previously housed under G. oppositifolius, a species known to occur in both Australia and Malesia (Backer 1951). In G. oppositifolius the flowers are usually in fascicles of 3-10, they are always distinctly pedicellate (the pedicels being $2-7 \mathrm{~mm}$ long), there are $3-5$, not 2 , stamens per flower and the leaves are generally much larger (10-35 mm long, 4-13 mm wide) and often glabrous.

Compared to those in other Australian species, the flowers of G. sessiliflorus are inconspicuous and have just two stamens per flower with the anthers in close proximity to the stigma. These attributes suggest a high degree of self-pollination.

Seeds from Kakadu localities have smooth surfaces but those from the Edith River area, which includes the type, have at least partly tuberculate surfaces. Further collections are required to see if this difference is consistent between northern and southern populations.

Other specimens examined: Northern Territory: near billabong at Nourlangie Rock, $12^{\circ} 25^{\prime} \mathrm{S}, 130^{\circ}$ 53'E, 13 Oct. 1973, J. Burrell 1358 (DNA); Edith River area, 14 04' 58”S, 132 07' 01”'E, 19 Aug. 1999, C.R. Michell 2684 (DNA); Ja Ja, Kakadu, 14 Dec. 1979, N. Sanderson (DNA 39331).

\section{Key to species of Glinus L. in Australia}

1. Young branchlets with an indumentum of stellate hairs G. lotoides

1* Young branchlets glabrous or with simple hairs 2

2. Flowers sessile, single and axillary; stamens 2 G. sessiliflorus

2* Flowers all or mostly on distinct pedicels and normally several in an inflorescence; stamens 3 or more 3

3. Stamens 3-5; perianth segments 3-4.5 $\mathrm{mm}$ long G. oppositifolius

3. Stamens 15-20; perianth segments 6-7 mm long G. orygioides

\section{Acknowledgments}

I sincerely thank my wife Emma for the Latin diagnosis and Monika Osterkamp Madsen for the excellent illustration.

\section{References}

Backer, C. A. (1951) Aizoaceae. Flora Malesiana Series I, 4: 267-275.

Fosberg, F. R. (1995) Molluginaceae. Pp. 320-331 in Dassanayake, M.D. (ed.), A Revised Handbook to the Flora of Ceylon, vol. 9. (A.A. Balkema: Rotterdam). 
